\title{
AUTHENTICATION OF THE REGION AS THE OBJECT OF ECONOMIC SECURITY IN THE CONTEXT OF ECONOMIC DEVELOPMENT OF UKRAINE \\ IVANOVA Natalia ${ }^{1}$
}

\begin{abstract}
The urgency of the research involves the need to define the procedure for determination of the region belonging in the system of the regional economic security; depending on the presented identifier (cluster).The development of discriminative models of the region authentication is expedient to define its belonging to particular category of the regional economic security. The objective of this article is to develop the mathematical models of the region authentication in relation to the status of their economic security using the discriminant analysis. The region identification cluster is the indicator of grouping. The article rationalizes the expediency of using the method of discriminant analysis while researching the regional economic security according to data of social and economic development of the region. As a result of clustering of regions by social and economic development, three statuses of the regional economic security were defined: "good", "sufficient" and "satisfactory". The classification functions of authentication of the region as the object of anti-crisis management for ensuring the regional economic security were developed for the specified classes by method of discriminant analysis. The evaluation of accuracy of the obtained functions indicates the expediency of their using. In addition, the article describes the authentication procedure of the region as the object of anti-crisis management for ensuring the regional economic security. The application of multidimensional statistical methods while researching the multi-criteria economic systems, such as socio - economic development of the region, allows exploring a large number of indicators with different measurement units, to identify the homogeneity of system objects. As a result of application of the discriminant analysis' method, the classification functions of authentication of the region as the object of anti-crisis management for ensuring the regional economic security were developed.

Keywords: anti-crisis management; regional economic security; multidimensional statistical methods; cluster analysis, discriminant analysis.

JEL Codes:C38, F52, R58
\end{abstract}

\section{Introduction}

Under conditions of decentralization of the regional governance, the question of the regional economic security is of particular attention. That rise of the question of development and implementation of the effective anti-crisis regional management for ensuring the economic security both at the meso-level and at the state level. There is a need for clearly defined methods of the region authentication in the system of the regional economic security, which will allow to define the current status of the economic security of the region and to receive the forecast in case of changes of the indicators.

Target setting. The development of models for definition of status of the economic security of the region by method of discriminant analysis is expedient.

Actual scientific researches and issues analysis. Such scientists as V.M. Heiets

1 IVANOVA Natalia, PhD (Economics), Associate Professor, E-mail: natalya4915@gmail.com, ivanova@donnuet.edu.ua, Educational and Scientific Institute of Management and Administration, Donetsk National University of Economics and Trade

Named after Mykhailo Tugan-Baranovsky (Kryvyi Rih), Ukraine 
(2006), B.A. Karpinskyi (2008), O.M. Holovchenko (2008), S.P. Stetsenko (2013), H.O. Sukrusheva (2015) and others dealt with the problems of the regional economic security.

The research of works of national scientists indicates the absence of the comprehensive approach to definition of status of the economic security of the region. The analytical researches of the regional economic security are carried out as monitoring of indicators of social and economic development of the regions in dynamics and relative to deviations with recommended threshold values. The economic security of the region is characterized by a large number of indicators with their own measurement units and dimensions.

There is a need to develop the models of the region authentication according to status of their economic security, which will allow defining comprehensively the status of the economic security taking into account the degree of impact of each component.

The objective of this article is to develop the discriminant models of the regional economic security classes, which will allow to defining comprehensively the status of the economic security taking into account the degree of impact of each component. Besides we included in the Annex a general view of economic development of Ukraine.

\section{Theoretical Aspects of Authentication of the Region in the System of Regional Economic Security}

The results of earlier theoretical research of the categories "region", "economic security" and "regional economic security" allowed us to clarify the definition of "regional economic security". Regional economic security is a set of properties of the regional economic system (regional administrative unit) that ensures stability, firmness and economic development of the region, competitiveness, a certain independence and, at the same time, integration with the national economy under conditions of destabilizing impact of different kinds' threats and decentralization (Ivanova, 2018). Regional economic security is represented by a complex indicator, which includes many characteristics and depends on many factors.

At present, there is no generally accepted methodology for calculating of regional economic security at the state level. The existing methodology for calculating of the economic security's level of Ukraine was integrated at the regional level by scientists (Sukhorukov, Kharazishvili, 2013) and was presented in the form of methodological recommendations, which was perfected and tested by Gumenyuk (2014). These scientists consider indicators of the regional socio-economic development as indicators of the level of economic security of the regions.

According to the methodological explanations of the State Statistics Service of Ukraine, the following main socio-economic indicators of the development of the regions identified are: the number of available population as of January 1, thousands persons; number of employees engaged in economic activity, thousands persons; available income per capita, UAH; expenditures of the population per one person, UAH; average monthly salary, UAH; consumer price index (December to December of the previous year), percent; Gross Regional Product (at current prices), mln. UAH; volume of sold industrial products (goods and services), mln. UAH; agricultural products (at constant prices), mln. UAH (including crop production, livestock production); acceptance into operation of the total area of the dwelling, ths. $\mathrm{m}$ 2; retail turnover of enterprises (at current prices), mln. UAH; the volume of sales of services, mln. UAH .; export of goods, mln. USD; import of goods, mln. USD; export of services, mln. USD; imports of services, mln. USD; financial result before taxation, bln. UAH; (excluding the results of budget organizations); capital 
investments (at current prices), bln. UAH.

The result of the data processing of these indicators by the discriminant analysis method is discriminant functions, based on which the process of authentication of the region is implemented. The definition of "authentication" (from Greek - is real or true) is treated as a procedure for establishing of belonging information to the user in the system of the presented identifier by him (Cabinet of Ministers of Ukraine, 2006). In determining the region's belonging to one or another category of economic security, we propose to apply the same term "authentication", while the region's identifiers are the values of socio-economic indicators for the relevant period, in addition, the identification process occurs at the stage of cluster analysis.

So, in the aspect of the state of economic security, we consider the category of "authentication of the region" as a procedure for establishing the region's belonging in the system of economic security according to the values of its socio-economic development's indicators. The result of the implementation of the region's authentication phase is to determine the region's belonging to one of the three categories of the economic security system "good", "sufficient" and "satisfactory".

\section{Socio-economic development of regional clusters of Ukraine}

In previous researches, the clustering of the regions of Ukraine by indicators of social and economic development resulted in the identification of the region homogeneity within the respective clusters that allowed defining 3 clusters (table 1).

Table 1. Clusters of the regions by status of the economic security (Ivanova, 2017)

\begin{tabular}{|c|c|c|}
\hline Cluster 1 ("sufficient") & Cluster 2 ("satisfactory") & Cluster 3 ("good") \\
\hline Vinnytsia & Volyn & Dnipropetrovsk \\
\hline Kirovohrad & Zhytomyr & Donetsk \\
\hline Mykolaiv & Zakarpattia & Zaporizhia \\
\hline Poltava & Ivano-Frankivsk & Kyiv \\
\hline Sumy & Luhansk & Lviv \\
\hline Kherson & Rivne & Kharkiv \\
\hline Khmelnytsky & Ternopil & \\
\hline Cherkasy & Chernivtsi & \\
\hline Chernihiv & & \\
\hline
\end{tabular}

Source: Developed by the author

The results of cluster analysis allowed to identify regional disproportions of socioeconomic development and to identify the homogeneity of objects (regions) of the system of management of regional economic security. The results of the study of the dynamics of disposable income and expenditures of population in the context of specific regional clusters are presented in Table. 2.

The data presented in the table indicate the difference between the cluster "Good": for the indicators of 2008-2015, the represented regional cluster has the highest values for the parameters of disposable income, expenditures and average monthly wages of the population.

At the regional level, the summary indicator that characterizes the level of economic development in the region is the Gross Regional Product (GRP). The Gross Regional Product at market prices is defined as the sum of the gross added value of all economic activities, including net taxes on the products. 
Table 2. Dynamics of indicators «Disposable Existing population income", "Population expenditures" and "Average monthly wages", 2008-2015 (by regional clusters).

\begin{tabular}{|c|c|c|c|c|}
\hline Year & Cluster & $\begin{array}{c}\text { Disposable } \\
\text { Existing population } \\
\text { income, UAH }\end{array}$ & $\begin{array}{c}\text { Population } \\
\text { expenditures, } \\
\text { UAN }\end{array}$ & $\begin{array}{l}\text { Average monthly } \\
\text { wages, UAH }\end{array}$ \\
\hline \multirow{3}{*}{$\begin{array}{c}2008 \\
(1 \mathrm{UAH}=0,09 \\
\text { EUR })\end{array}$} & Cluster "Good" & 14373,33 & 16808,87 & 1776,71 \\
\hline & Cluster "Sufficient " & 12543,06 & 13605,16 & 1468,78 \\
\hline & Cluster "Satisfactory" & 11284,34 & 12508,65 & 1473,38 \\
\hline \multirow{3}{*}{$\begin{array}{c}2009 \\
(1 \mathrm{UAH}=0,09 \\
\text { EUR })\end{array}$} & Cluster "Good" & 15209,74 & 17501,13 & 1881,00 \\
\hline & Cluster "Sufficient " & 12797,49 & 14192,43 & 1575,56 \\
\hline & Cluster "Satisfactory" & 11558,49 & 13227,91 & 1566,38 \\
\hline \multirow{3}{*}{$\begin{array}{c}2010 \\
(1 \mathrm{UAH}=0,09 \\
\text { EUR })\end{array}$} & Cluster "Good" & 18869,96 & 21075,29 & 2206,71 \\
\hline & Cluster "Sufficient " & 16021,07 & 16650,30 & 1861,33 \\
\hline & Cluster "Satisfactory" & 14421,88 & 15887,89 & 1864,00 \\
\hline \multirow{3}{*}{$\begin{array}{c}2011 \\
(1 \mathrm{UAH}=0,09 \\
\text { EUR })\end{array}$} & Cluster "Good" & 21919,67 & 25791,09 & 2608,43 \\
\hline & Cluster "Sufficient " & 18636,06 & 20503,81 & 2163,11 \\
\hline & Cluster "Satisfactory" & 16999,46 & 19461,80 & 2144,50 \\
\hline \multirow{3}{*}{$\begin{array}{c}2012 \\
(1 \mathrm{UAH}=0,09 \\
\text { EUR })\end{array}$} & Cluster "Good" & 24689,59 & 29103,20 & 2964,14 \\
\hline & Cluster "Sufficient " & 20781,16 & 23319,39 & 2505,00 \\
\hline & Cluster "Satisfactory" & 18759,18 & 22223,14 & 2472,13 \\
\hline \multirow{3}{*}{$\begin{array}{c}2013 \\
(1 \mathrm{UAH}=0,09 \\
\text { EUR })\end{array}$} & Cluster "Good" & 27013,46 & 31682,60 & 3185,00 \\
\hline & Cluster "Sufficient " & 22728,19 & 24991,24 & 2703,78 \\
\hline & Cluster "Satisfactory" & 20429,94 & 23306,18 & 2674,63 \\
\hline \multirow{3}{*}{$\begin{array}{c}2014 \\
(1 \mathrm{UAH}=0,05 \\
\text { EUR })\end{array}$} & Cluster "Good" & 28152,83 & 35290,30 & 3379,00 \\
\hline & Cluster "Sufficient " & 23885,64 & 28931,41 & 2890,33 \\
\hline & Cluster "Satisfactory" & 20446,29 & 25976,50 & 2827,25 \\
\hline \multirow{3}{*}{$\begin{array}{c}2015 \\
(1 \mathrm{UAH}=0,04 \\
\text { EUR })\end{array}$} & Cluster "Good" & 31314,54 & 42318,43 & 4134,14 \\
\hline & Cluster "Sufficient " & 28310,72 & 37401,38 & 3449,22 \\
\hline & Cluster "Satisfactory" & 23290,59 & 32014,54 & 3298,63 \\
\hline
\end{tabular}

The volume of realized industrial products (goods and services) is determined by the selling price of finished products shipped (goods and services), which is indicated in the documents as basis for the calculation of the buyer (customers) documents (including products (goods, services) under a barter contract).

The results of the study of the GRP indicators' dynamics and the volume of realized industrial products in the context of regional clusters suggest the existence of positive trends to increase (Fig. 1). 


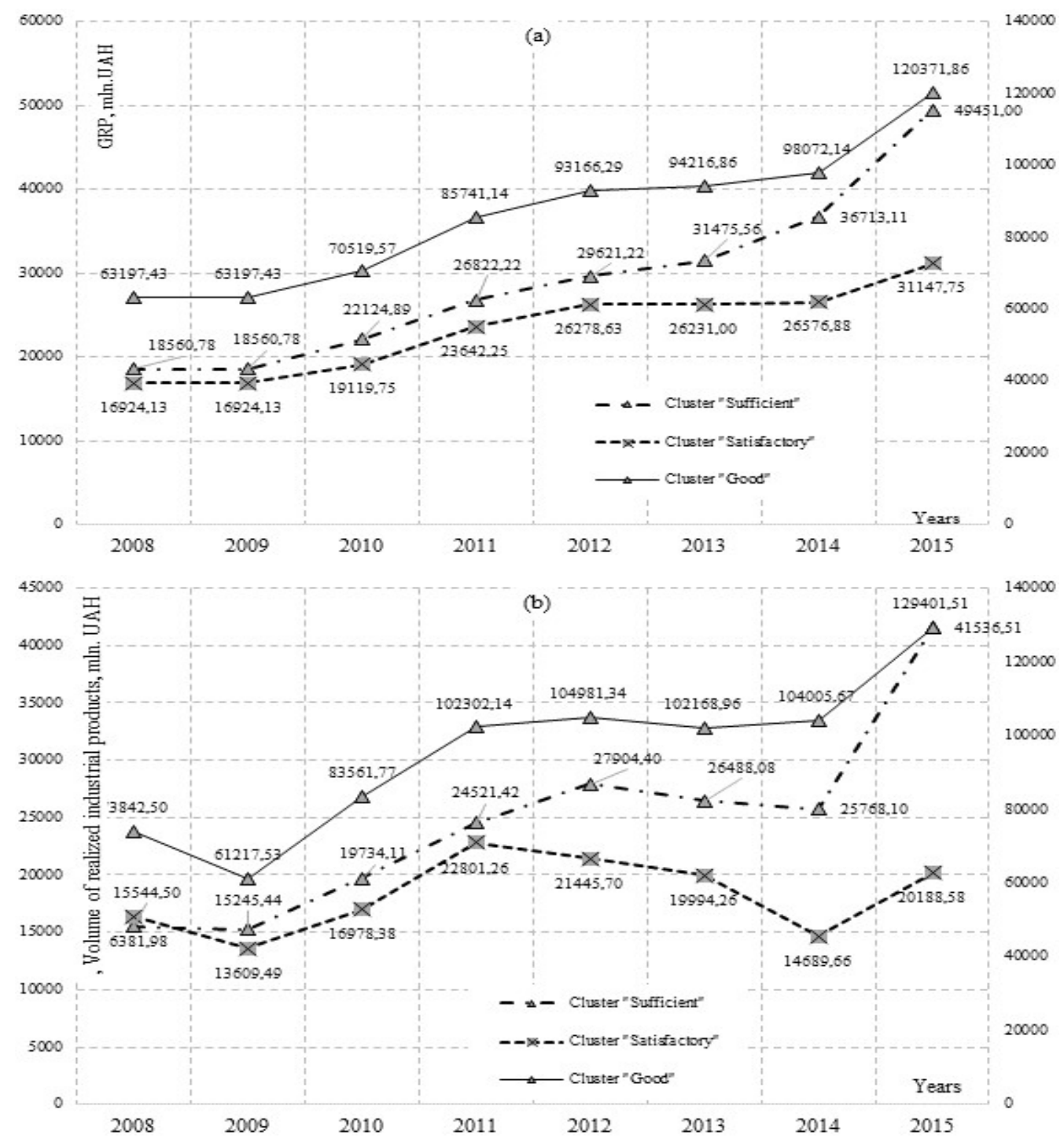

Figure 1. The GRP indicators' dynamics (a) and the volume of realized industrial products (b) in the context of regional clusters, $2008-2015(2008-2013: 1 \mathrm{UAH}=0,09$ EUR; 2014: 1 UAH = 0,05 EUR; 2015: 1 UAH = 0,04 EUR)

According to the results of a study of the socio-economic development of regional clusters in Ukraine, the following conclusions can be drawn:

- The regional cluster with the value of economic security "good" according to 2015 has the highest values of the following indicators: population, number people of economic activities, income and expenditures of the population, average monthly wages, gross regional product, volume of realized industrial goods, retail turnover of enterprises, export and import of goods and services. The average value is the indicator of the volume of agricultural production (including crop production).

-A regional cluster with a sufficient level of economic security is characterized by the highest value of agricultural output (including crop production); the average values of 
the following indicators: the number of people engaged in economic activity, the income and expenditures of the population, the average monthly wage, gross regional product, the volume of realized industrial goods, the retail turnover of enterprises, the export and import of goods and services.

- A regional cluster with a satisfactory level of economic security is characterized by the average value of the population indicator and the lowest values of all other indicators of socio-economic development of the region.

\section{Authentication of status of economic security of regions on indicators of their social and economic development}

Synthesis of differences allowed to characterize the determined clusters, but it is difficult to conduct authentication (on appropriate cluster - identifier) of region belonging to a particular cluster for subsequent periods according to the obtained results. The answer to this problem is to develop a discriminant function for each cluster.

Discriminant function is a linear combination of a certain set of features, which are called the classification ones and on the basis of which the classes are identified. The special aspect of discriminant function is that the classes are represented by scale of items and the classification features $\mathrm{x}_{\mathrm{i}}$, where $\mathrm{i}=1,2$, $\mathrm{m}$ are measured with metric scale. The last number cannot exceed $(n-2)$, where $n-$ the population size (Yerina, 2001).

Discriminant function $f_{j}$ is determined for each $j$ class $(j=1,2, \ldots, p)$ :

$$
f_{j}=a_{0 j}+a_{1 j} \bar{x}_{1 j}+a_{2 j} \bar{x}_{2 j}+\ldots+a_{m j} \bar{x}_{m j}
$$

where,

$\mathrm{a}_{\mathrm{ij}}-$ index of function (no conceptual interpretation);

$\bar{x}_{i j}$ - average of i feature in the $\mathrm{j}$ class.

Calculations of discriminant functions of regional economic safety classes were conducted by Statistica 10 (Discriminant Analysis).

The initial data are the materials of State Statistics Service of Ukraine (Regions of Ukraine. Statistical Yearbook, 2015) on social and economic development of regions of Ukraine in 2015: The current population, thsd. $\left(\mathrm{X}_{1}\right)$; Number of the employed, thsd. $\left(\mathrm{X}_{2}\right)$; Current income of population UAH / Person $\left(\mathrm{X}_{3}\right)$; Personal expenditures $\left(\mathrm{X}_{4}\right)$; Average salary, UAH ( $\left.\mathrm{X}_{5}\right)$; The consumer price index $\left(\mathrm{X}_{6}\right)$; Gross regional product, mln. UAH. $\left(\mathrm{X}_{7}\right)$; Volume of industrial products sold, mln. UAH. ( $\left.\mathrm{X}_{8}\right)$; Agricultural products, mln. UAH. (X); Crop production, mln. UAH. $\left(\mathrm{X}_{10}\right)$; Livestock products, mln. UAH $\left(\mathrm{X}_{11}\right)$; The commissioning of total housing area, thousand $\mathrm{m} 2\left(\mathrm{X}_{12}\right)$; Retail turnover of enterprises, mln. UAH $\left(\mathrm{X}_{13}\right)$; Export of goods, mln. USD ( $\left.\mathrm{X}_{14}\right)$; Import of goods, mln. USD (x15); Export of services, mln. USD (X16); Import of services, mln. USD ( $\left.\mathrm{X}_{17}\right)$; Financial result before tax (profit) bln. UAH $\left(\mathrm{X}_{18}\right)$; Financial result before tax (loss) bln. UAH (X19); Capital investments bln. UAH (X20).

The results of dispersion analysis of built clusters showed no significant differences (i.e. the significance level is greater than 0.05) for the following indicators: $\mathrm{X}_{6}-$ the consumer price index $(p=0,57) ; X_{11}-$ livestock products $(p=0,19) ; X_{12}-$ the commissioning of housing area $(p=0,12)$. This indicates that the average values of the studied parameters are different for this level of significance, and therefore these figures were excluded from the data sample.

A characteristic feature of the analysis of social and economic development of 
regions is quite a number of values (indicators) that are often measured in different scales, and that is why it is necessary to use standardized (normalized) data. The standardization and normalization of data are intended to bring all indicators into one value (make them comparable). This procedure is performed by the expression:

$$
y_{i j}=\frac{x_{i j}-\overline{x_{j}}}{\delta_{j}}
$$

where, $\mathrm{x}_{\mathrm{ij}}-\mathrm{i}$ realization of $\mathrm{j}$ feature, $\bar{x}_{j}$ - the average arithmetic value of the $\mathrm{j}$ feature,

$\sigma_{j}$ - the standard deviation of the $\mathrm{j}$ feature.

Evaluation of classification result by method of discriminant analysis indicates the correct classification: index of Wilks' lambda $(\lambda)$ equals to 0.00278 , and according to the theory $\lambda$ values that are close to 0 indicate a high distinctive ability of discriminant function. Thus, the obtained results of the conducted calculations of discriminant function are able to determine the status of regional economic security with minimal probability of error. The parameters of discriminant function for each of the selected classes are presented in Table 3.

Table 3. Functions of regional economic security classification

\begin{tabular}{|l|c|c|c|}
\hline & «ood» & «Sufficient» & «Satisfactory» \\
\hline $\mathrm{X} 1$ & 122,73 & $-54,01$ & $-46,63$ \\
\hline $\mathrm{X} 2$ & $-73,75$ & 27,21 & 33,92 \\
\hline $\mathrm{X} 3$ & 43,81 & $-11,57$ & $-25,32$ \\
\hline $\mathrm{X} 4$ & $-1,96$ & $-1,56$ & 3,48 \\
\hline $\mathrm{X} 5$ & $-11,20$ & 2,50 & 6,99 \\
\hline X7 & $-28,97$ & 22,40 & 0,16 \\
\hline $\mathrm{X} 8$ & 15,42 & $-1,60$ & $-11,69$ \\
\hline $\mathrm{X} 9$ & $-32,73$ & 13,33 & 13,65 \\
\hline $\mathrm{X} 10$ & $-0,24$ & 7,38 & $-8,09$ \\
\hline $\mathrm{X} 13$ & 68,88 & $-32,63$ & $-23,57$ \\
\hline $\mathrm{X} 14$ & $-7,87$ & $-1,57$ & 8,65 \\
\hline X15 & 30,86 & $-5,16$ & $-21,20$ \\
\hline X16 & 7,08 & 1,58 & $-7,97$ \\
\hline X17 & $-82,64$ & 27,18 & 41,74 \\
\hline X18 & 61,98 & $-33,82$ & $-16,19$ \\
\hline X19 & $-1,47$ & $-4,13$ & 5,94 \\
\hline X20 & $-4,79$ & $-1,78$ & 6,19 \\
\hline Constant & $-73,19$ & $-14,72$ & $-17,14$ \\
\hline
\end{tabular}

Source: Calculated by the author

According to the data of Table 3 it was developed the following classification functions of economic security of regions (3) - (5): formula (3):

- Regional economic security "good" (RES $S_{\text {good }}$ ) is described by the following 


$$
\begin{gathered}
\text { RES }_{\text {good }}=122,74 X_{1}-73,75 X_{2}+43,82 X_{3}-1,96 X_{4}-11,2 X_{5}-28,97 X_{7}+ \\
+15,43 X_{8}-32,73 X_{9}-0,24 X_{10}+68,89 X_{13}-7,87 X_{14}+30,86 X_{15}+ \\
+7,08 X_{16}-82,64 X_{17}+61,98 X_{18}-1,48 X_{19}-4,79 X_{20}-73,19
\end{gathered}
$$

- Regional economic security "sufficient" (RES sufficient) is described by the following formula (4):

$$
\begin{gathered}
\text { RES }_{\text {sufficient }}=-54,01 X_{1}+27,21 X_{2}-11,57 X_{3}-1,56 X_{4}+2,5 X_{5}+22,4 X_{7}- \\
\quad-1,6 X_{8}+13,33 X_{9}+7,38 X_{10}-32,63 X_{13}-1,58 X_{14}-5,16 X_{15}+ \\
\quad+1,58 X_{16}+27,18 X_{17}-33,82 X_{18}-4,13 X_{19}-1,78 X_{20}-14,72
\end{gathered}
$$

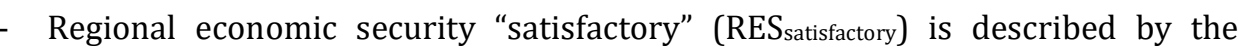
following formula (5):

$$
\begin{aligned}
\text { RES }_{\text {satisfactory }}= & -46,63 X_{1}+33,92 X_{2}-25,32 X_{3}+3,48 X_{4}+6,99 X_{5}+0,16 X_{7}- \\
-11,69 X_{8} & +13,65 X_{9}-8,1 X_{10}-23,57 X_{13}+8,66 X_{14}-21,2 X_{15}-7,97 X_{16}+ \\
& +41,74 X_{17}-16,19 X_{18}+5,94 X_{19}+6,19 X_{20}-17,14
\end{aligned}
$$

The examination of developed functions confirmed their correctness. Thus, the results of calculations using formulas (3) - (5) with the actual data of socio - economic development of regions for 2015 reflect the results of previously conducted cluster analysis (Fig. 2).

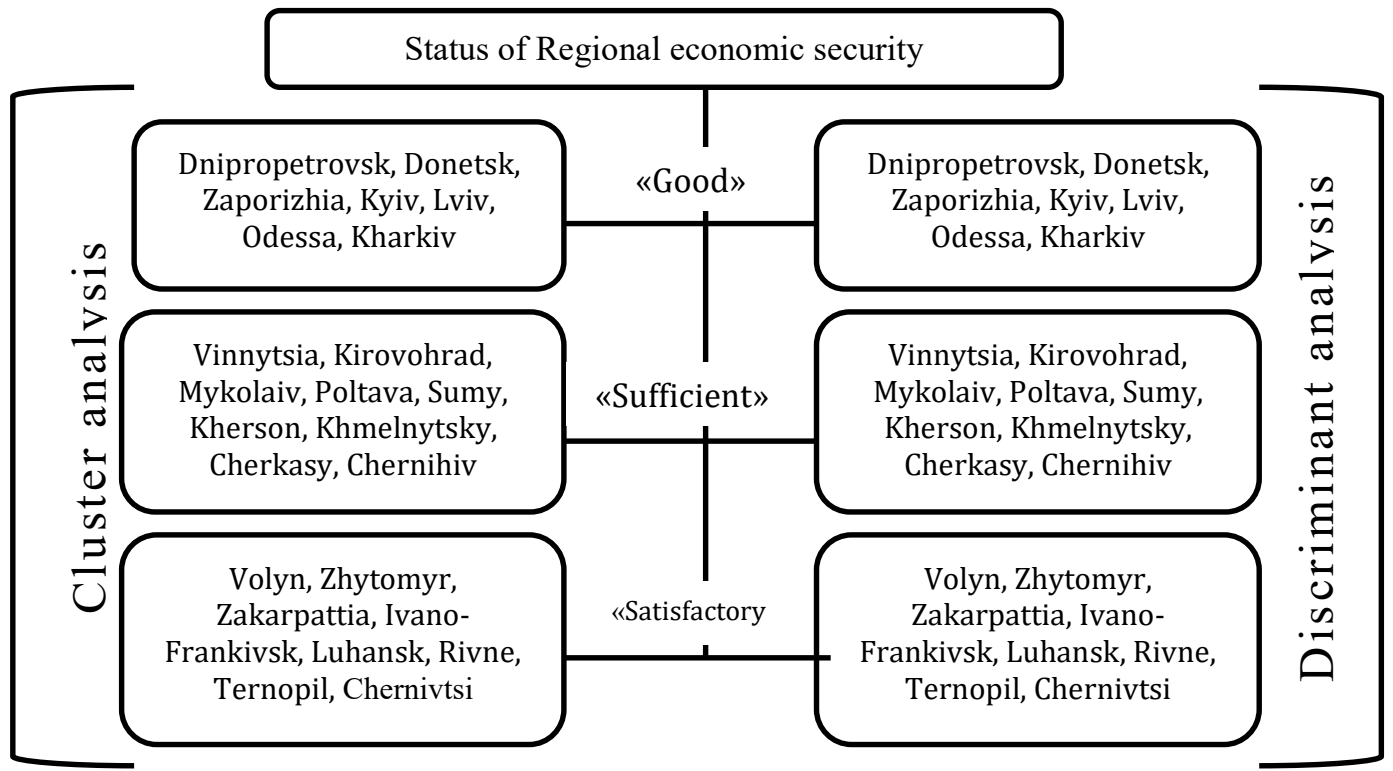

Figure 2. Authentication results of status of economic security of regions on indicators of their social and economic development

Source: developed by the author

The results of comparative analysis of some regions of different clusters are presented in Table 4. 
Table 4. Comparison of components of discriminatory functions of different clusters' some regions: Dnipropetrovsk region ("Good"), Mykolaiv region ("Sufficient"), Chernivtsi region ("Satisfactory")

\begin{tabular}{|c|c|c|c|c|c|c|c|c|}
\hline \multirow{2}{*}{\multicolumn{2}{|c|}{ Variable }} & \multirow{3}{*}{$\begin{array}{c}\text { "Good" } \\
3254,9\end{array}$} & \multirow{3}{*}{$\begin{array}{c}\text { "Sufficient" } \\
973,1\end{array}$} & \multirow{3}{*}{$\begin{array}{c}\text { "Satisfactory" } \\
909,9\end{array}$} & \multicolumn{4}{|c|}{ Deviation } \\
\hline & & & & & \multicolumn{2}{|c|}{$\begin{array}{l}\text { "Satisfactory" } \\
\text { from "Good" }\end{array}$} & \multicolumn{2}{|c|}{$\begin{array}{c}\text { "Satisfactory" from } \\
\text { "Good" }\end{array}$} \\
\hline $\begin{array}{l}\text { The current } \\
\text { population, thsd. }\end{array}$ & $\mathrm{X} 1$ & & & & $-2281,8$ & $-70,1$ & -2345 & $-72,0$ \\
\hline $\begin{array}{l}\text { Number of the } \\
\text { employed, thsd. }\end{array}$ & $\mathrm{X} 2$ & 1479,6 & 386,8 & 367,2 & $-1092,8$ & $-73,9$ & $-1112,4$ & $-75,2$ \\
\hline $\begin{array}{l}\text { Current income of } \\
\text { population UAH / } \\
\text { Person }\end{array}$ & X3 & 38346,2 & 26728,4 & 23490,5 & $-11617,8$ & $-30,3$ & $-14855,7$ & $-38,7$ \\
\hline $\begin{array}{l}\text { Personal } \\
\text { expenditures }\end{array}$ & $\mathrm{X} 4$ & 47453,6 & 37014 & 32953,1 & $-10439,6$ & $-22,0$ & $-14500,5$ & $-30,6$ \\
\hline Average salary, UAH & $\mathrm{X} 5$ & 4366 & 3282 & 3050 & -1084 & $-24,8$ & -1316 & $-30,1$ \\
\hline $\begin{array}{l}\text { Gross regional } \\
\text { product, mln. UAH }\end{array}$ & $\mathrm{X} 7$ & 176540 & 28758 & 15049 & -147782 & $-83,7$ & -161491 & $-91,5$ \\
\hline $\begin{array}{l}\text { Volume of industrial } \\
\text { products sold, mln. } \\
\text { UAH }\end{array}$ & X8 & 301107,8 & 22980,8 & 6817,6 & -278127 & $-92,4$ & -294290 & $-97,7$ \\
\hline $\begin{array}{l}\text { Agricultural } \\
\text { products, mln. UAH }\end{array}$ & X9 & 15141,4 & 11000,4 & 4287,4 & -4141 & $-27,3$ & -10854 & $-71,7$ \\
\hline $\begin{array}{l}\text { Crop production, } \\
\text { mln. UAH }\end{array}$ & $\mathrm{X} 10$ & 10673,9 & 9056,8 & 2638,5 & $-1617,1$ & $-15,2$ & $-8035,4$ & $-75,3$ \\
\hline $\begin{array}{l}\text { Retail turnover of } \\
\text { enterprises, mln. } \\
\text { UAH }\end{array}$ & $\mathrm{X} 13$ & 47718,4 & 8555,4 & 7659,2 & -39163 & $-82,1$ & $-40059,2$ & $-83,9$ \\
\hline $\begin{array}{l}\text { Export of goods, } \\
\text { mln. USD }\end{array}$ & $\mathrm{X} 14$ & 6399 & 406,6 & 108,3 & $-5992,4$ & $-93,6$ & $-6290,7$ & $-98,3$ \\
\hline $\begin{array}{l}\text { Import of goods, } \\
\text { mln. USD }\end{array}$ & X15 & 3225,3 & 105,4 & 78,4 & $-3119,9$ & $-96,7$ & $-3146,9$ & $-97,6$ \\
\hline $\begin{array}{l}\text { Export of services, } \\
\text { mln. USD }\end{array}$ & $\mathrm{X} 16$ & 294,4 & 27,8 & 20,5 & $-266,6$ & $-90,6$ & $-273,9$ & $-93,0$ \\
\hline $\begin{array}{l}\text { Import of services, } \\
\text { mln. USD }\end{array}$ & $\mathrm{X} 17$ & 402,1 & 22,6 & 1,8 & $-379,5$ & $-94,4$ & $-400,3$ & $-99,6$ \\
\hline $\begin{array}{l}\text { Financial result } \\
\text { before tax (profit) } \\
\text { bln. UAH }\end{array}$ & X18 & 34,5 & 10,4 & 1,5 & $-24,1$ & $-69,9$ & -33 & $-95,7$ \\
\hline $\begin{array}{l}\text { Financial result } \\
\text { before tax (loss) bln. } \\
\text { UAH }\end{array}$ & X19 & $-81,1$ & $-14,6$ & $-1,1$ & 66,5 & 82,0 & 80 & 98,6 \\
\hline $\begin{array}{l}\text { Capital investments } \\
\text { bln. UAH }\end{array}$ & $\mathrm{X} 20$ & 25,9 & 4,1 & 2,8 & $-21,8$ & $-84,2$ & $-23,1$ & $-89,2$ \\
\hline
\end{tabular}

Source: Calculated by the author

The data in Table 3 shows that the highest value of identifiers is in Dnipropetrovsk Region, which belongs to a regional cluster "good". The exception is the indicator "Financial result before tax (loss)", the value of which Chernivtsi region is higher by $98 \%$. According to the data analysis of Table 2 it can be concluded that the disproportion of economic security of Dnipropetrovsk and Chernivtsi regions on average 67.1\%; Dnipropetrovs'k region and Mykolayiv region amount an average of $-57 \%$.

\section{Results}

The accuracy of the obtained classification functions indicates the possibility to use them for definition of status of the regional economic security for the following periods. In addition, the functions allow defining the forecast status of the regional economic security 
by forecast values of socio-economic development of the regions.

The procedure of authentication of the regional economic security is shown in Fig. 3: 1. Definition of the research object (region). 2. Data sampling of indicators of socioeconomic development of the region. 3. Standardization of indicators included in the sampling. 4. Calculation of values of the classification functions of the regional economic security.

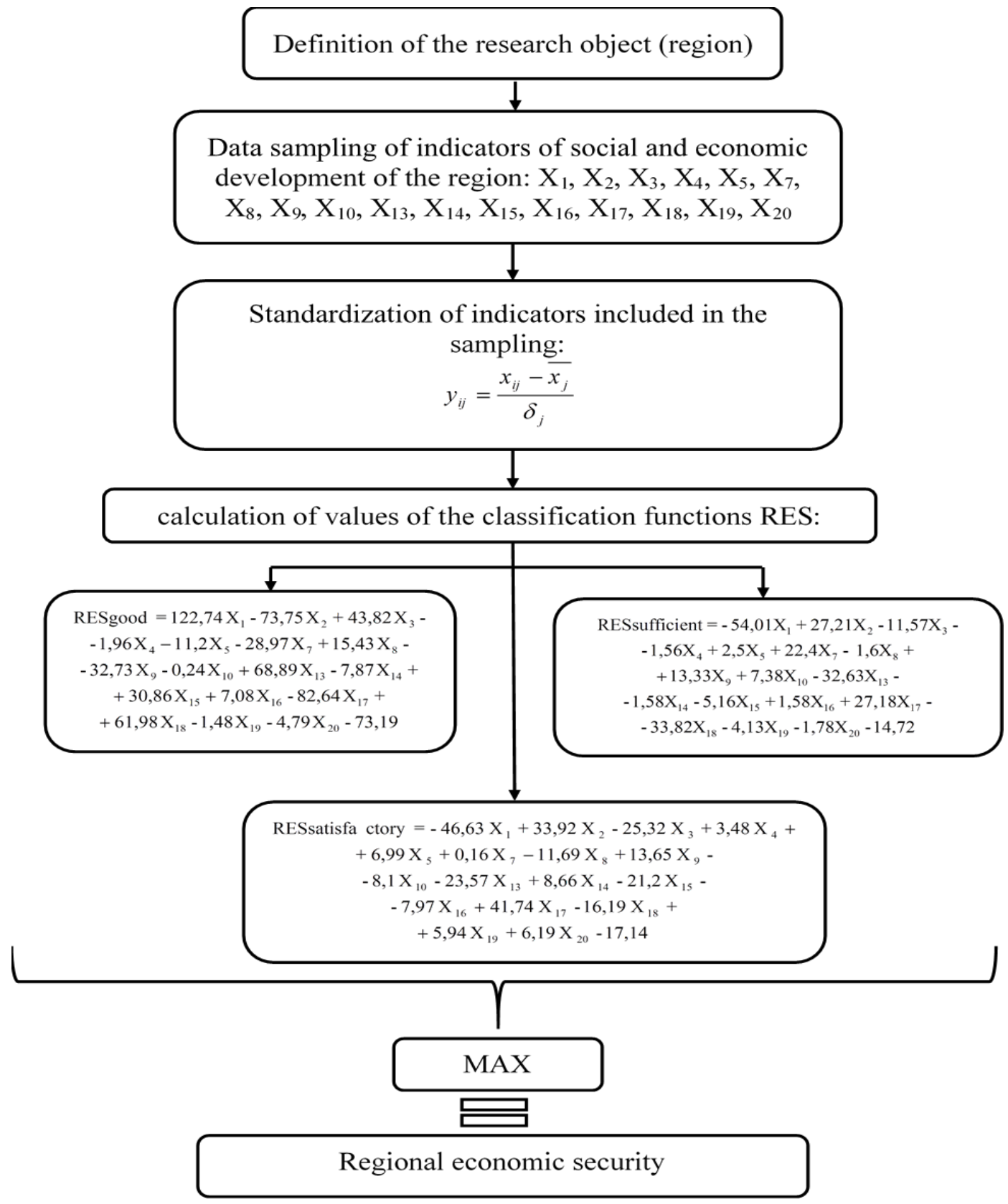

Figure 3. Procedure of authentication of the region as the object of anti-crisis management for ensuring the regional economic security. Source: Compiled by the author 
At the first stage it is necessary to define the research of the object, namely, the region, which status of economic security is to be defined. The data sample of indicators of socio-economic development of the corresponding region for the period is formed and the procedure of standardization (normalization) of the data is performed with the using of the formula (2). The data may be automatically standardized with the using of the programs Statistica or SPSS, which have corresponding built-in modules.

The data, which were obtained as a result of normalization, are used in formulas (3) - (5) and calculations are made. The research object belongs to that class ("good", "sufficient", "satisfactory"), for which individual values of the discriminant functions are bigger. The decision concerning the system of anti-crisis management of regional development to ensure the economic security of the region is made according to the results of calculations.

\section{Conclusion.}

The application of multidimensional statistical methods while researching the multi-criteria economic systems, such as social and economic development of the region, allows exploring a large number of indicators with different units of measurement, to identify the homogeneity of system objects. And there is no exception, when it comes to the discriminant analysis that allowed to develop the classification functions of authentication of the region as the object of anti-crisis management for ensuring the regional economic security. Three statuses of the regional economic security were defined: "good", "sufficient" and "satisfactory". The accuracy of functions is confirmed by Wilks' lambda and approbation according to actual data.

\section{References}

Guisan, M.C., Aguayo, E. (2003). Education, Industry, Trade and Development of European and Eurasian Countries in 1980-99. Applied Econometrics and International Development, Vol. 3.1. At: http://www.usc.es/economet/eaat.htm

Guisan, M.C. (2017). Manufacturing And Development In Countries And Areas Of Europe And Eurasia, 2000-2010, Regional and Sectoral Economic Studies, Vol. 17-1.

Guisan, M.C., Exposito, P. (2018). Economic Development Problems and Crisis in the European Union, 2005-2015. Applied Econometrics and International Development, Vol. 181, free on line at: http://www.usc.es/economet/eaat.htm.

GumenyuK, A. M. (2014). Security structural and institutional transformation of the regional economy: the theoretical foundations and practical aspects: monograph. Kyiv: NISD, $468 \mathrm{p}$.

Heiets, V. M., Kyzym, M. O., Klebanova, T. S. \& Cherniak, O. I. (2006): “Modeling of economic security: state, region, enterprise", Kharkiv: INZhEK

Holovchenko, O.M. (2008): "Economic security of the region as a guarantee of stability of the national economy: a monograph", Odesa: Bukaiev Vadym Viktorovych,

Ivanova, N.S. (2017): "Identification of homogeneity of objects of anti-crisis management system by cluster method". Marketing and management of innovations, vol.4, pp. 188198.

Ivanova, N.S. (2018): "Theoretical analysis of the definition of "regional economic security". Journal of Volyn Institute for Economics and Management, vol.20 (1), pp. 126-132. 
KarpinskyI, B.A. (2008): "Indicators of financial security in the context of balancing the financial system". Scientific bulletin Polissya, vol. 18.2, pp. 131-145

Ministry of Economy(2007). On approval of the methodology of calculating the level of economic security of Ukraine. Order of the Ministry Ukraine's economy, in 2.03.2007 Available at: http://www/expert-ua.info/document/archivepa/law5xwqoi/index.htm

Ministers of Ukraine (2006). Resolution of the Cabinet of Ministers of Ukraine On Approval of the Rules for the Protection of Information in Information, Telecommunication, and Information-Telecommunication Systems No. 373 of March 29,http://www.dsszzi.gov.ua/dstszi/control/uk/publish/article?art_id=47960\&cat_id $=38834$ (Accessed 22 November 2017).

State Statistics Service Of Ukraine (2015): Regions of Ukraine. Statistical Yearbook. Kyiv: State statistics service of Ukraine.

State Statistics Service Of Ukraine (2018) : http://www.ukrstat.gov.ua. (November 21)

Stetsenko, S. P. (2013): "Theoretical aspects of the study of the economic security of the region on the basis of socio-economic monitoring", Investytsiyi: praktyka ta dosvid, vol.23, pp. 121-123.

Sukhorukov, A.I., Kharazishvili, Yu. M. (2013): The effectiveness of the socio-economic development and economic security of the region (for example, Carpathian region): Analytical note. Kyiv, $32 \mathrm{p}$.

Sukrusheva, H. O. (2015): "The theoretical aspects of the concept of "economic security of the region". Foreign trade, economics, finance, law, vol.3, pp. 231-238.

Yerina, A.M. (2001): "Statistical design and prognostication”, Kyiv: KNEU

\section{Annex: Economic development of Ukraine}

The comparison of economic development of Ukraine with other European and Eurasian countries, shows the following evolution:

Period 1980-1999: As seen in Guisan and Aguayo(2002) production per capita of Ukraine increased for the period 1980-1990 and experienced a strong decrease for the period 1990-1999 as well as in other countries of the same area, evolving from 8228 in 1980 to 9366 in 1990 and only 3919 in 1998 (US Dollars at 1999 prices and Parities). Industrial production per capita evolved from 3620 in 1980 to 4121 in 1990 and only 1372.

Period 2000-2015. Accordingly to Guisan(2017), Gross Domestic Product per capita evolved from 3696 to 6029 (in US Dollars ar 2005 prices and Parities), while the average of the same Area (Russia, East Europe and CIS) evolved from 6038 to 10208 and World average from 7905 to 9852 . Manufacturing production per capita was below the Area and the World averages, evolving from 702 to 904, while the Area evolved from 1052 to 1527 and the World average from 1494 to 1728.

It is very important to increase industrial production per head in order to favor economic development of services and other areas and to reach better positions in real income per capita.

Journal RGE: http://www.usc.es/econo/RGE/benvidag.htm 